\title{
Design of an equipment for polishing of medical vagin dilators in order to eliminate edges and burrs
}

\section{Diseño de un equipo pulidor de dilatadores vaginales médicos para la eliminación de filos y rebabas}

\author{
ROJAS-GARNICA, Juan Carlos†ं*, MUÑOZ-MATA, José Lorenzo, CERVANTES-DE LA ROSA, \\ Juan Pedro and OCOTITLA-MUÑOZ, Alma Delia
}

Universidad Tecnológica de Puebla

ID 1 ${ }^{\text {st }}$ Autor: Juan Carlos, Rojas-Garnica / ORC ID: 0000-0002-2261-587X, CVU CONACYT ID: 66417

ID $1^{\text {st }}$ Coautor: José Lorenzo, Muñoz-Mata / ORC ID: 0000-0001-7813-5579, CVU CONACYT ID: 177117

ID $2^{\text {nd }}$ Coautor: Juan Pedro, Cervantes-De la Rosa / ORC ID: 0000-000I-6634-2018

ID $3^{\text {rd }}$ Coautor: Alma Delia, Ocotitla-Muñoz / ORC ID: 0000-0002-3266-3226, CVU CONACYT ID: 851782

DOI: $10.35429 /$ JSL.2021.25.8.1.8

Received June 30 2021; Accepted December 30, 2021

\begin{abstract}
In medical applications, specifically in the handling of mechanical utensils, hygiene and safety must be ensured, which implies a complete cleaning and sterilization of these, as well as the absence of burrs on support edges, in order that there are no harmful cuts of the tissues that are being examinated or manipulated. In such a way, the socalled mirrors or vaginal dilators are very useful elements in the review of women's health and should not be exempt from the minimum quality of hygiene and safety. These devices, are developed using a special polymer, which are commonly elaborated through plastic injectors using molds, due to, they are implemented using different parts, generate the creation of sharp edges and shavings that must be eliminated. The geometry of the mirrors implies a certain complexity in the elimination of the cutting elements. In the present work the design of a polishing machine is presented, which is designed under the principle of fusion of sharp edges and shavings by applying heat from butane gas flames. The proposed machine transports the mirrors to the position to the location of the heating source, with the proper orientation, in order to eliminate the edges and shavings.
\end{abstract}

Deburring, Polishing Machine, Plastic Vaginal Dilators

\begin{abstract}
Resumen
En aplicaciones médicas, específicamente en el manejo de utensilios mécanicos, debe asegurarse la higiene y seguridad, lo cual, implica una completa limpieza y esterilización de estos, así como la ausencia de filos en bordes de sustentación para que no existan cortes perjudiciales en tejidos que se estén examinando o manipulando. En ese sentido, los denominados espejos o dilatadores vaginales, son elementos muy útiles en la revisión de la salud de las mujeres y no deben estar exentas de calidad mínima en higiene y seguridad. Estos dispositivos, hechos con un polímero especial, son comúmente elaborados por medio de la inyección del plástico en moldes, debido a que, al estar construidos de diferentes partes, generan la creación de bordes filosos y virutas que deben ser eliminados. La geometría de los espejos, implica una cierta complejidad en la eliminación de elementos cortantes. El presente trabajo presenta el diseño de una máquina pulidora que funciona bajo el principio de fusión de los bordes filosos y virutas aplicando calor proveniente de flamas de gas butano. La máquina propuesta transporta los espejos hacia la posición donde se encuentra la fuente de calor, con la orientación adecuada, para que estas alcancen los bordes y virutas a eliminar.
\end{abstract}

Desbarbado, Máquina de pulido, Dilatadores vaginales plásticos

Citation: ROJAS-GARNICA, Juan Carlos, MUÑOZ-MATA, José Lorenzo, CERVANTES-DE LA ROSA, Juan Pedro and OCOTITLA-MUÑOZ, Alma Delia. Design of an equipment for polishing of medical vagin dilators in order to eliminate edges and burrs. Journal Simulation and Laboratory. 2021, 8-25: 1-8

*Correspondence to Author (email: carlos.rojas@utpuebla.edu.mx)

$\dagger$ Researcher contributing as first Author. 


\section{Introducción}

In order to perform operations or medical examinations, the tools and auxiliary elements must be sterilized and free of sharp edges and shavings that could damage the tissues that are subject to manipulation.

Vaginal mirrors devices are one of the auxiliary elements used to verify good health in women, which are developed using a transparent polymer, through the injection process using molds, which generate certain undesirable edges and shavings.

On the other hand, the devices geometry is complex, therefore, removing the edges and shavings is a difficult process to implement.

For the elimination of these waste material, a deburring and/or a polishing process can be performed, for this purpose, a circular fine-grained stone rotating a determined speed could be used.

In addition, to remove burrs, cones with sharp grooves are used. Another approach is using micro-abrasion with high pressure water with micro particles of carbon, or using laser systems that perform fusion or cutting of shavings in the areas of interest (Lamikiz et al. 2007) or use chemical agents to erode shavings (Chen et al., 2019; Zhao and Chang, 2002).

To achieve all points of interest, deburring or polishing tools can be guided on complex trajectories using five degrees of freedom robotic devices (Guo et al. 2019).

Another approach to cover the areas of interest is through the regulation of the deburring trajectories using of a 5-axis CNC machine (Pessoles and Tournier 2009).

In this work, the design of a machine is presented, which uses the heat of flame source of liquefied petroleum gas affecting directly the sites of interest. Using this approach, the edges and shavings are melted in order to achieve the polishing of the critical areas.

The design of this system will allow to the company SYM Laboratorios S.A. de C.V. to achieve a higher productivity in the process of polishing the dilating mirrors with a relatively low investment.

\section{Proposed design description}

The mechanical proposed design was implemented using the CAD software CATIA (Torrecilla 2019).

\subsection{Mechanical-operational design}

Figure 1 and 2 shows the polishing assembly and the principal subassemblies. The subassemblies are listed below:

1. Guide feeder

2. Capacitive sensor assembly

3. Belt drive system with blades

4. Capacitive sensor assembly

5. Burner 1

6. Burner 2

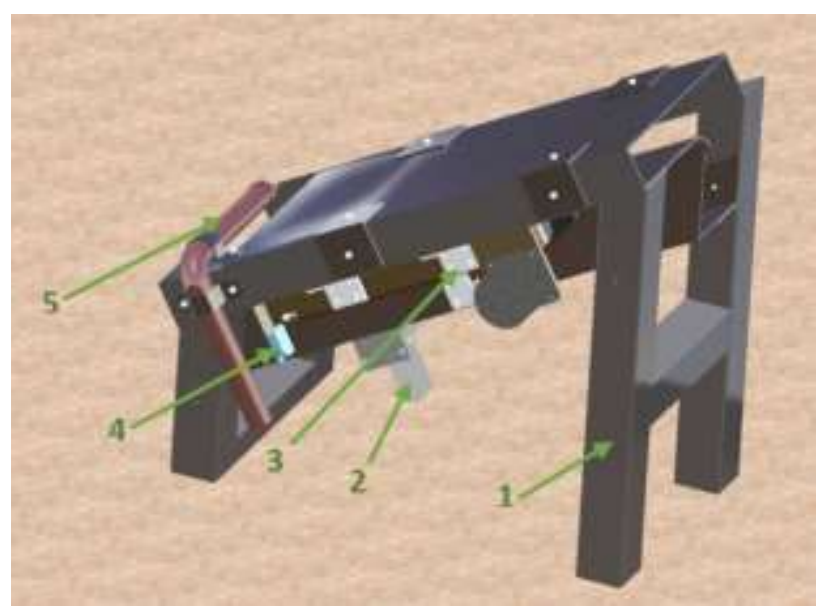

Figure 1 View 1 of the designed polishing equipment Source: Own Elaboration

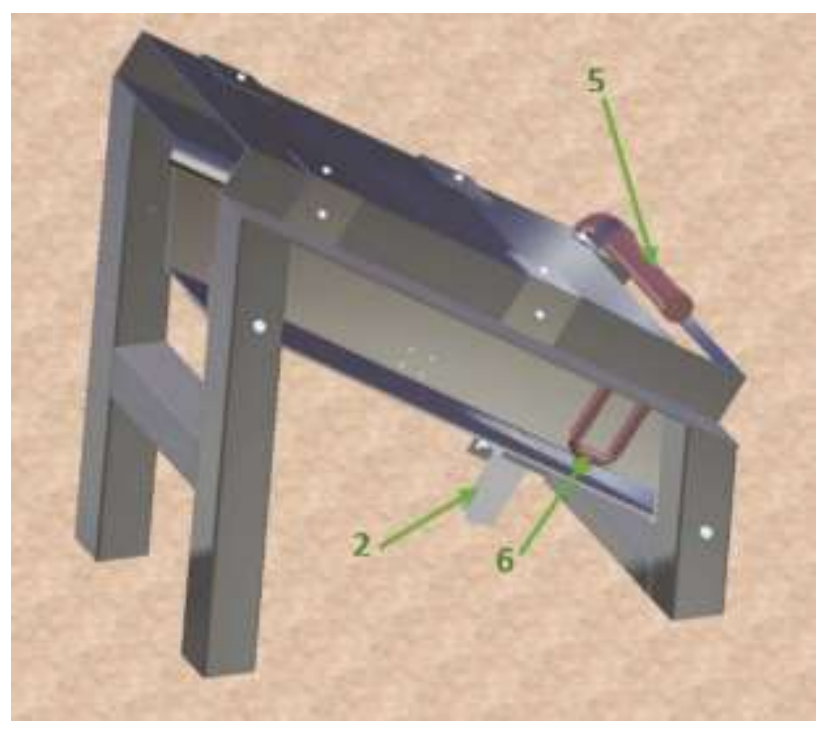

Figure 2 View 2 of the designed polishing equipment Source: Own Elaboration 
The Guide Feeder consists of a structure that supports the entire process, it is based on two long supports of two-inch PTR profile made of 1018 steel, part 1 of Figure 3. Moreover, two short supports (Figure 3, part 2), of the same profile and same material as Figure 3 part 1. With this lenght difference, a slope of $30^{\circ}$ is obtained, allowing an initial sliding of the mirrors. Over the four supports, two angular joists are welded with dimensions of two inches of 1018 steel (Figure 3, part 3), which support a sliding base (Figure 3, part 4), and a roof (Figure 3 , part 5).

The sliding base has an end in the shape of an arc of a circumference in order to facilitate the coupling of the mirrors when they slide inside the structure. This base use 7075 aluminum, as well as the material considered for the roof. Both the sliding base and the roof are joined to the angular joists through bolted joints supported by angular supports using the same material (Figure 3 , part 7). In order to reinforce the structure, two crossbars are welded using the same profile and material as the supports (Figure 3, part 8).

The initial orientation to adjust the mirror to polish is shown in Figure 4. Due to the inclination, this mirror slides until it meets one of the blades of the drive system.

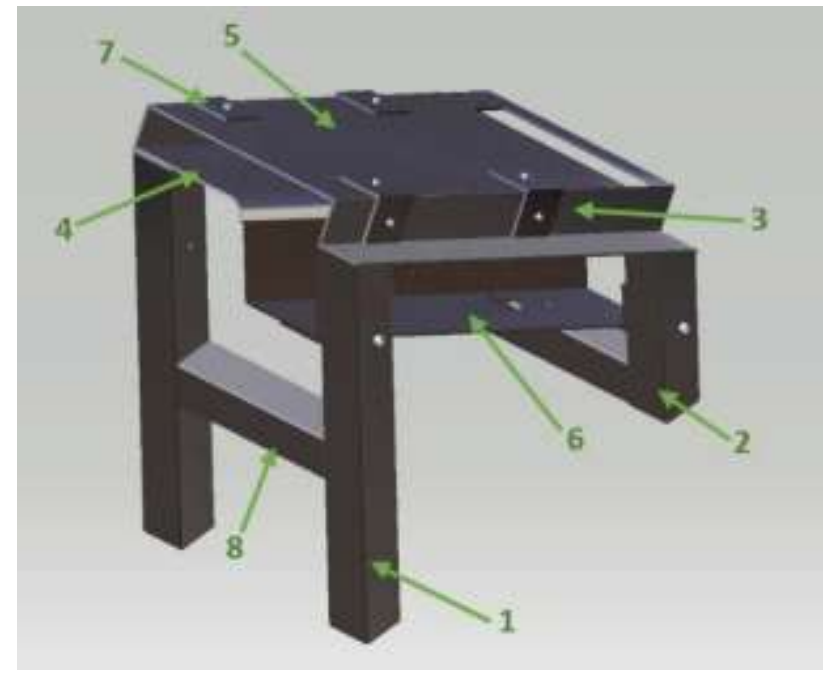

Figure 3 Guide feeder of the designed polishing equipment

Source: Own Elaboration

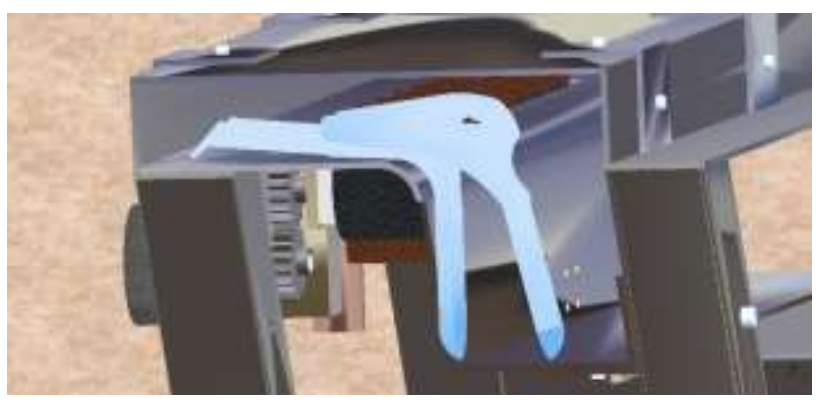

Figure 4 Mirror in the Guide feeder, at the beginning of the polishing process

Source: Own Elaboration

The belt and blade drive system can be observed in Figure 5. As can be observed, the drive system is mounted at the bottom of the sliding base, conecting the system structure (Figure 5, part 1), to the feeder-guide assembly using screws. A $100 \mathrm{~W}$ direct current electric motor is mounted on this structure (Figure 5, part 2 ), through a pair of gears, (Figure 5, part 3), with a $2 \mathrm{~mm}$ module and 18 teeth, allows the rotation of a roller 1 (Figure 5, part 4). Using the roller 2 (Figure 5, part 5), it is possible to tension and pull a band (Figure 5, part 6).

The band contains a series of blades (Figure 5, part 7), with sufficient spacing between them to hold and drag one mirror per blade. Using this subassembly, only one mirror is located to the burner area with a constant speed, which can be regulated using the motor through the electronic system. In order to verify the position of the blades, the optical sensor showed in Figure 1 is used. This sensor is aligned towards the body of the blades in a determined position, where it is possible to verify the presence of any jam in the feed.

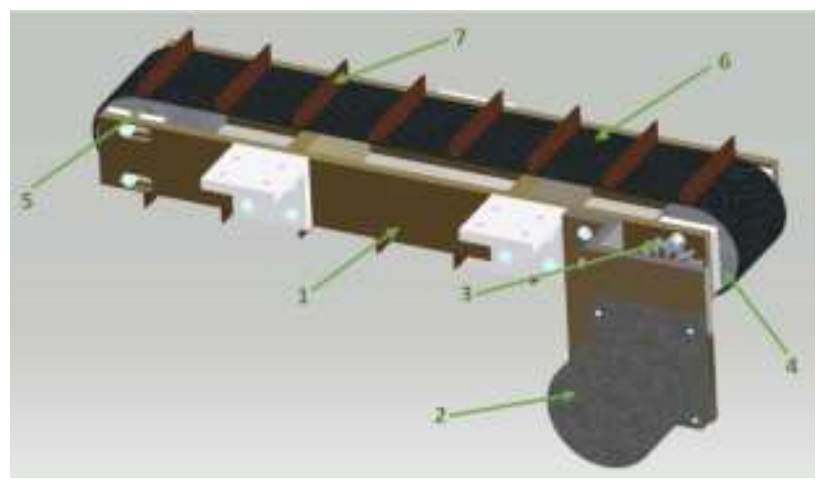

Figure 5 Belt and blade drive system on designed polishing equipment

Source: Own Elaboration 
Figure 6 shows the movement of a vaginal mirror device towards the burners área though the band with Blades.

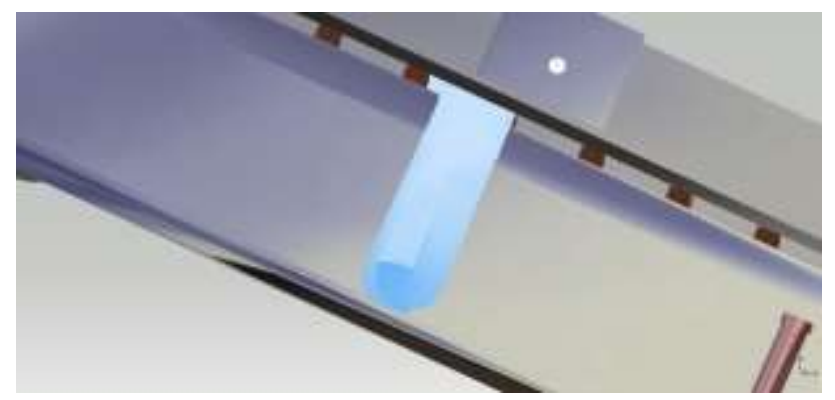

Figure 6 Dragging a mirror by means of the belt and blade system on the designed polishing equipment Source: Own Elaboration

Figure 7 shows a zoom-in towards the optical sensor, which detects the position of the blades through the lower part of the drag system.

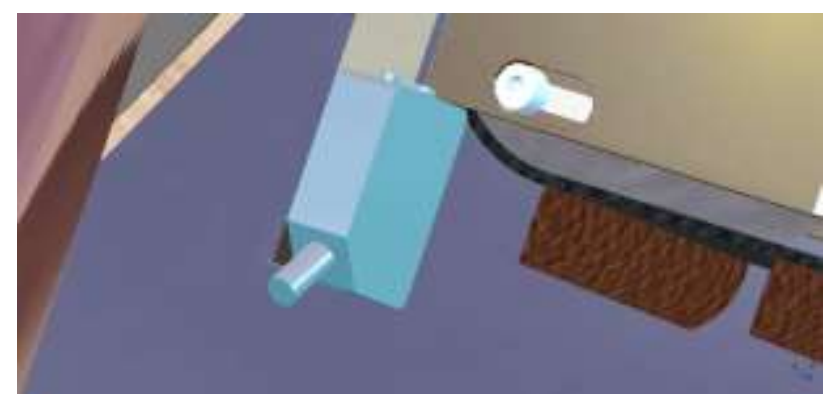

Figure 7 Optical sensor in the designed polishing equipment

Source: Own Elaboration

In Figure 8, the burner 1 can be observed, which is located on the roof of the mechanism. This roof has a cutting that allows the burner of LP gas flames to achieve the top of the mirror assembly. These flames arise from a copper tube, part 1 of Figure 8, with perforations in two rows of perforations at $45^{\circ}$ of separation at the lower position. This tube is welded with an elbow joint (Figure 8, part 2), moreover, this joint is welded to a gas feed tube (Figure 8, part 3).

The burner 1, is fixed using two clamps (Figure 8, part 4), screwed at the roof and to one of the joists with an angle profile. The diameter and lenght dimension of the tube depends of the size of the mirrors to be polished. The range considered for the diameter and lenght of the burner is from 10 to $20 \mathrm{~mm}$ and from 50 to 70 $\mathrm{mm}$ respectively.

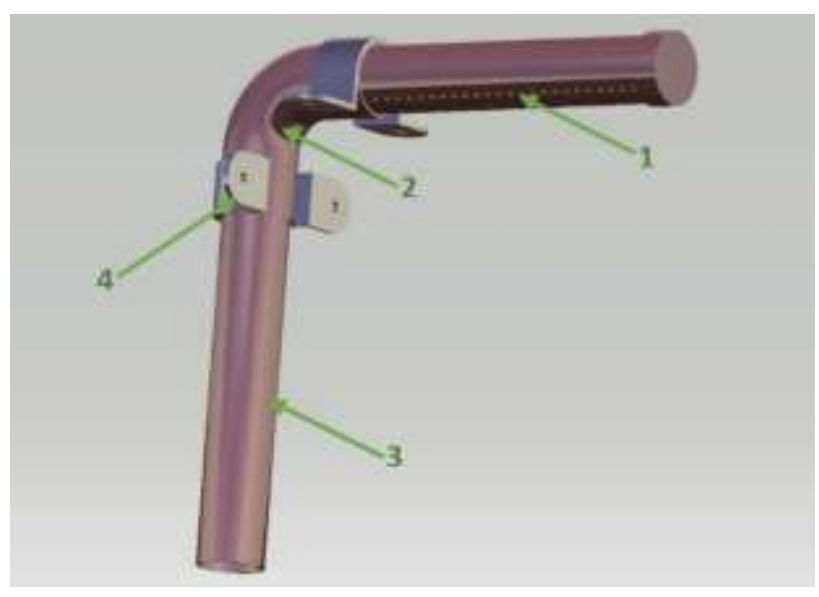

Figura 8 Burner 1 of the designed polishing equipment Source: Own Elaboration

The burner 2, shown in Figure 9, which is located at the bottom, on the sliding joist. It consists of a copper T-joint (Figure 9, part 1), with a thread to facilitate its connection to the joist, using two screws, one above and one below the joist (Figure 9, part 2). The T-joint is welded to two Elbow joints (Figure 9, part 3). These elbow joints are welded to a pipe (Figure 9, part 4), with a seal at the end (Figure 9, part 5).

The T-joint, elbows and pipes are perforated with $5 \mathrm{~mm}$ of separation and at both sides of the diameter to guarantee a uniform application of heat at the two inferior parts of the mirror assembly through the flame generated from the LP gas. The dimensions of the diameters and height of the burner are adjusted according to the size of the mirrors to be polished, considering a diameter range of 10 to $20 \mathrm{~mm}$ and a height range of 50 to $70 \mathrm{~mm}$.

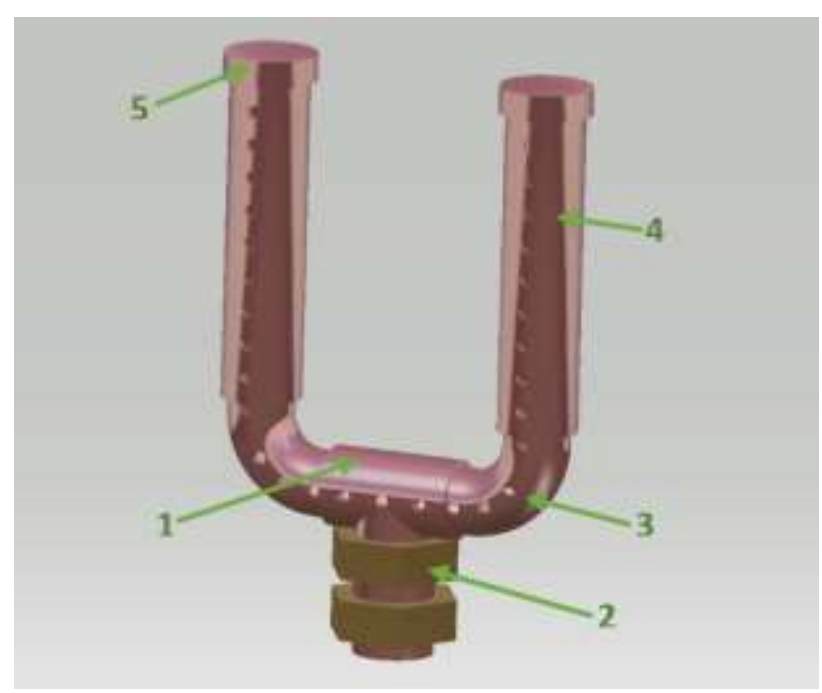

Figura 9 Burner 2 of the designed polishing equipment Source: Own Elaboration 
Figure 10 shows the advance of a mirror through the burner area. Is also shown, the capacitive sensor, which is located below the mirrors and whose function is to detect and count the parts to polish.

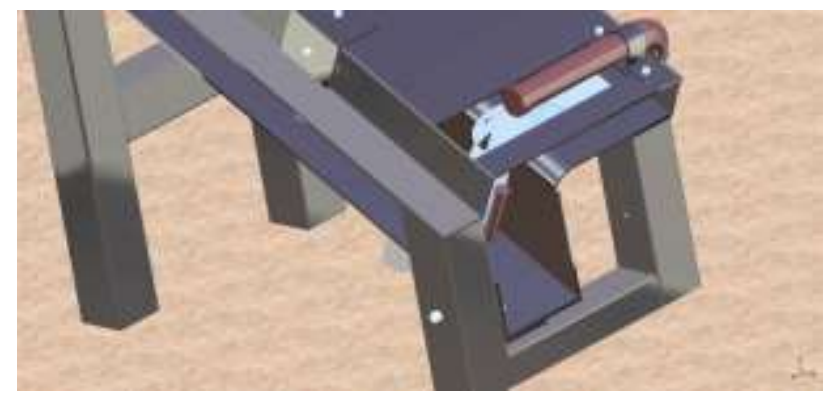

Figure 10 The passage of a mirror through the burner area Source: Own Elaboration

When the polishing process has been finished at the burner area, the mirror is expelled into a container by gravity, to continue to a review and packaging area.

\subsection{Electronic Design}

Once the mechanical design assembly as well as the subassemblies were completed, and having knowledge of the dynamics of the process, the electronic system was designed. Therefore, a programmable device was used for the implementation of an algorithm that contains the necessary logic for the automation of the designed mechanism. In such a way, be able to integrate a fully automated system. The block diagram of the electronic system is shown in Figure 11.

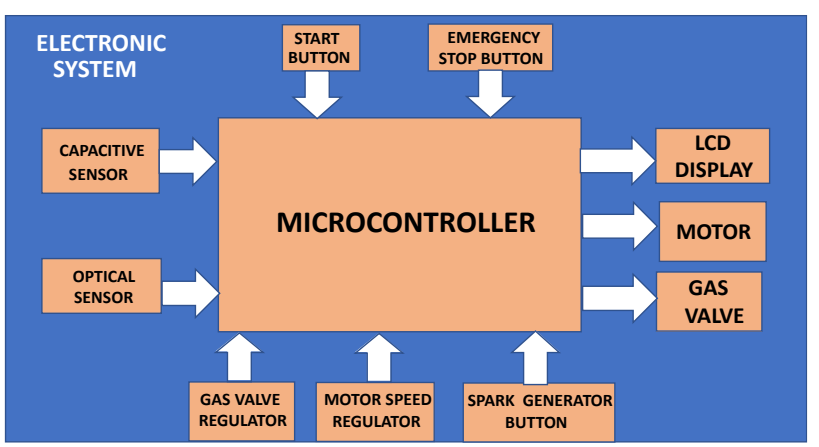

Figura 11 Block diagram of the designed electronic circuit Source: Own Elaboration

For the electronic design, a PIC 16F877A microcontroller (Microchip 2006) was used, which contains the firmware with the programming algorithm to control the process.

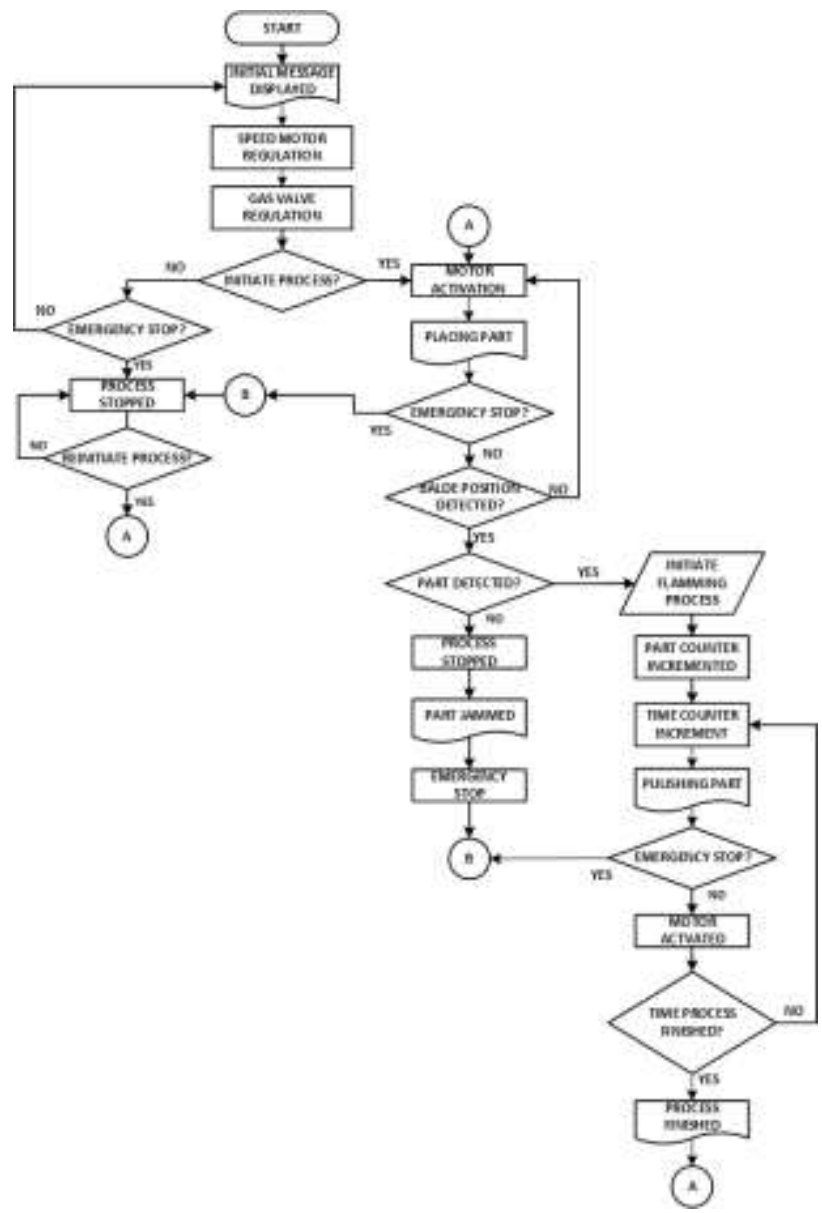

Figure 12 Flow chart of the firmware implemented Source: Own Elaboration

A system was developed which consists of a process start button, an emergency stop button. In addition, the electronic system has the ability to manipulate a $100 \mathrm{~W}$ DC motor to activate the mechanism. Such movement is conditioned by an optical sensor, which detects the adecuate position of the blades, subsequently, a capacitive sensor is used to detect the part correctly placed with respect to the position of the burners of the device, as well as to perform the part counting to be polished. Finally, it contains a spark generator to activate the flame and two regulators to control the opening and closing of a solenoid valve to regulate the gas output to modulate the intensity of the flame, as well as the speed of the motor to regulate the rotation of the blades to obtain a better performance of the system. A firmware was developed using the CCS compiler (García Trejo 2009).

\subsection{Firmware Design}

Figure 12 shows the flow chart corresponding to the firmware designed to control the process and integrate the electronics with the mechanical system. 
To iniciate the system, the motor remains stopped and an initial message is displayed requesting that the "PRESS START" button be pressed. If such button is not pressed, the systems asks if the emergency stop button is pressed, otherwise It is kept in an infinite cycle. In this loop it is only possible to adjust the burner flame through the solenoid valve and regulate the motor speed, until a start or an emergency stop event is generated. Subsequently, if the start button is pressed, a message of "PLACING PART" is displayed, which means that the motor moves the blades to place the vaginal mirror at the polishing position.

Once the motor sensor is activated, the motor stops and verifies if the part was placed correctly through the capacitive sensor, if the oart is not detected, the system displays the message "PART JAMMED", therefore, the system stops completely and ths system is in "EMERGENCY STOP" and the user can only restart the process until the part is liberated and the the start button is pressed.

On the other hand, if the piece is positioned correctly, the flaming process for polishing the vaginal mirror begins, indicated on the display as: "POLISHING PIECE". It is important to mention that the motor speed can be regulated from the control panel knob in case it is required to be able to accelerate or decelerate the process. Once the process is finished, the legend "PROCESS FINISHED" is displayed and the motor ia activated again to remove the polished piece and insert a new piece to start the cycle of the polishing process.

In the case of an event that threatens the system and it is necessary to stop the process, the electronic system constantly monitors the stop button to stop the entire system and correct the problem that occurs within or outside the process. Additionally, a spark generator was added to electronically ignite the burner that generates its flame.

Optionally, a second motor is proposed for the opening and closing of the gas valve to be carried out from a knob similar to the speed regulation knob for the mechanism motor.
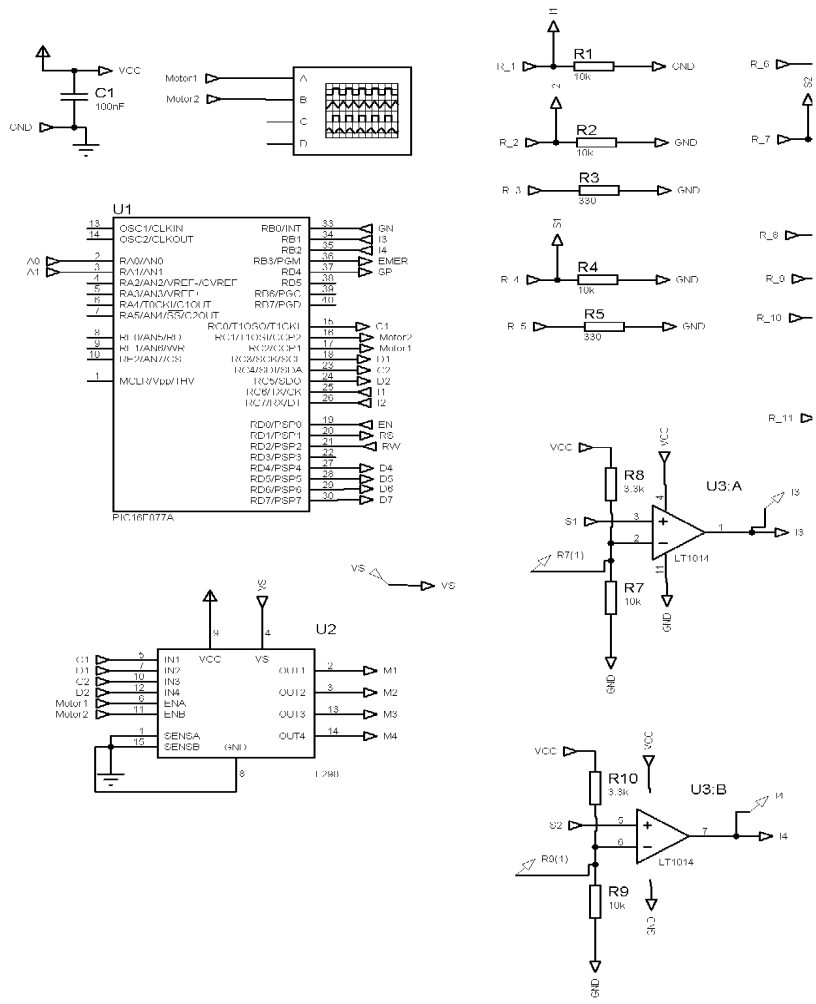

Figure 13 View 1 of the designed electronic diagram Source: Own Elaboration

Figure 13 and 14 shows the electronic diagram of the electronic system. It can be observed that it contains a motor driver to activate and to regulate the motor speed. Moreover, is shows the signal conditioning circuit of the sensors to detect the blades position, as well as the polishing part. Finally, the start and stop buttons, and the regulators knobs for the modulation of the flame intensity and the motor speed using Pulse Widith Modulation (PWM).

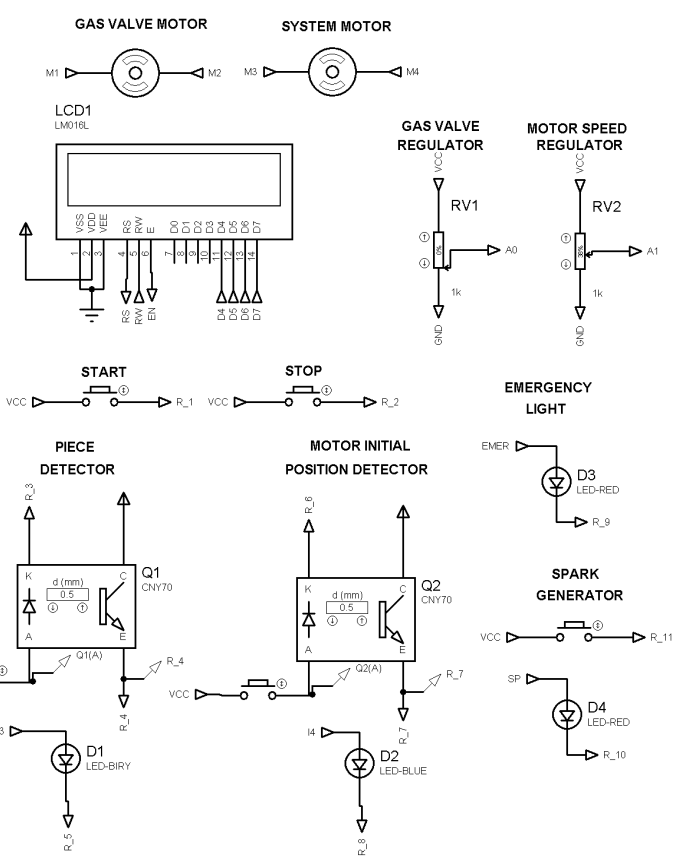

Figura 14 View 2 of the designed electronic diagram Source: Own Elaboration 


\section{Results}

Once both the mechanical system and the electronic system were designed, the assembly of the entire system was carried out. Figure 15 shows the assembly of the integrated mechanical system proposal.

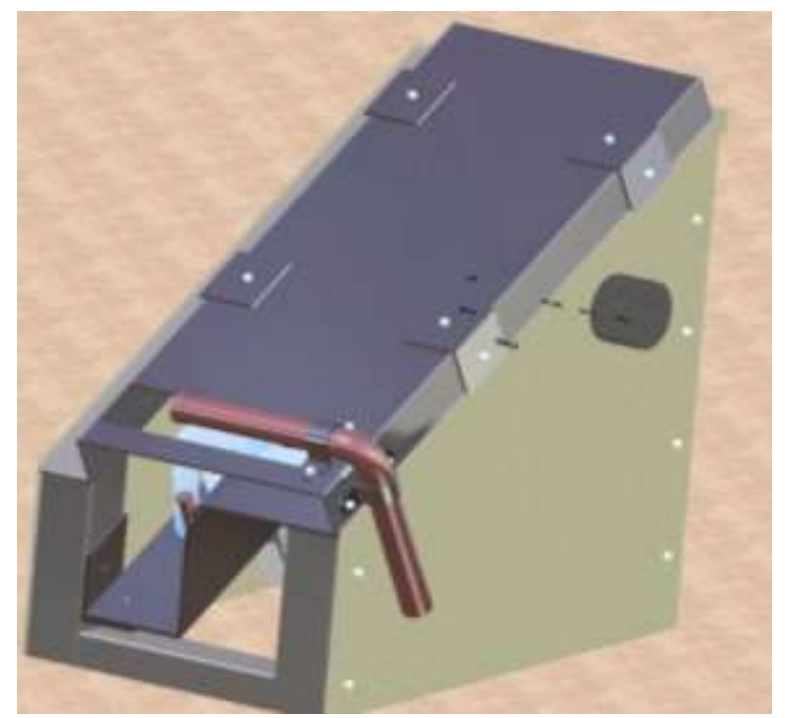

Figure 15 Mechanical design assembly completed Source: Own Elaboration

Figure 16 shows the proposal of the control panel for the electronic system, which contains the control logic to control the pulishing process. As can be observed, such panel contains the buttons and indicators necessary to control and monitoring the system.

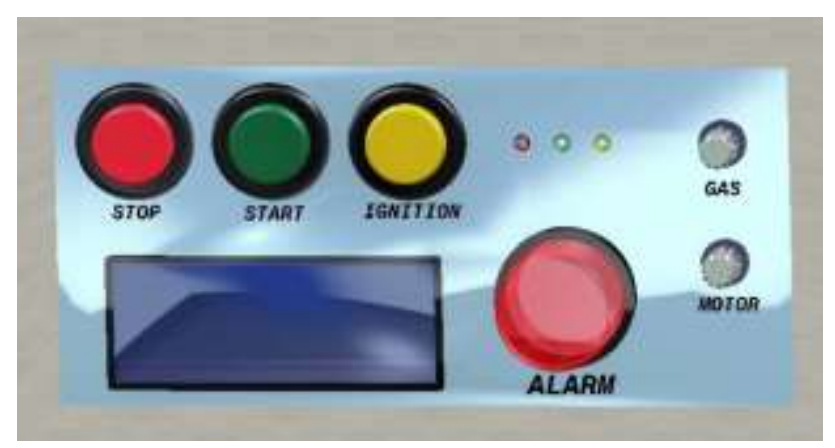

Figura 16 Mechanical design assembly completed Source: Own Elaboration

Finally, a fully integrated system was assembled to complete the design proposal, in order to fullfill the user requirements, as can be observed in Figure 17.

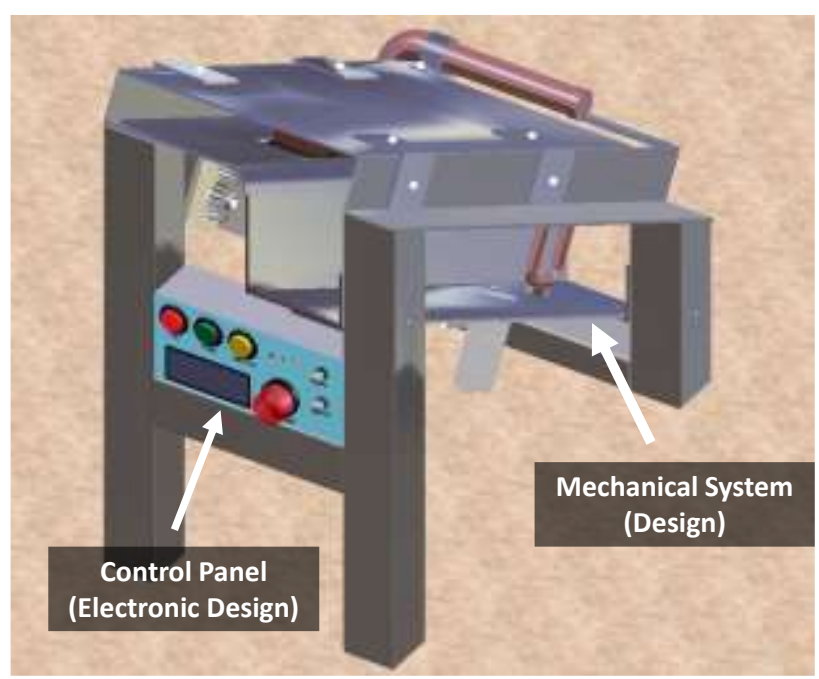

Figura 17 Full assembly proposal completed Source: Own Elaboration

With the development of this proposal, it is possible to reduce the polishing process time in at least $50 \%$ of the actual process, successfully achieving the expectations and requirements of the requesting company.

\section{Conclusions}

A system for polishing mirrors or vaginal dilators has been designed, with an estimated cost to manufacture of approximately $\$ 1,500$ dollars.

Likewise, the circuit for regulating the supply of the elements to be polished has been proposed.

The approach of this proposal is to support the local industry in the improving of the quality and productivity of the polishing process.

\section{Future work}

As future work, it is planned to perform an evaluation of the effectiveness and efficiency of the proposed approach, in order to improve the elaborated design.

\section{References}

Angulo J., S. Romero, Angulo I. (2004). Microcontroladoes PIC, Diseño práctico de Aplicaciones Segunda Parte (1a ed.). Madrid, España; Mc Graw Hill. 
Chen R., Li S., Wang Z., Lu X. (2019) Mechanical model of single abrasive during chemical mechanical polishing: Molecular dynamics simulation. Tribology International, Volume 133. Pages 40-46, ISSN 0301-679X, https://doi.org/10.1016/j.triboint.2018.12.018.

García Trejo E. (2009). Compilador C CCS y Simulador Proteus para Microcontroladores PIC ( $2^{\mathrm{a}}$ ed.). Ciudad de México, México: Alfaomega.

Guo, W., Li, R., Zhu, Y., Yang, T., Qin, R., \& $\mathrm{Hu}$, Z. (2019). A Robotic Deburring Methodology for Tool Path Planning and Process Parameter Control of a Five-Degree-ofFreedom Robot Manipulator. Applied Sciences, 9(10), 2033. MDPI AG. Retrieved from http://dx.doi.org/10.3390/app9102033.

Japan International Cooperation Agency. Tecnología de la producción 2019. https://openjicareport.jica.go.jp/pdf/11547668_ 03.pdf

Lamikiz A., Sánchez J.A., López de Lacalle L.N, Arana J.L. (2007). Laser polishing of parts built up by selective laser sintering. International Journal of Machine Tools and Manufacture, Volume 47, Issues 12-13. Pages 2040-2050. ISSN 0890-6955. https://doi.org/10.1016/j.ijmachtools.2007.01.0 13.

Microchip. (2006, 1 enero). PIC18F2455/2550/ 4455/4550 Data Sheet [Datasheet]. Recuperado 10 octubre, 2017, de https://ww1.microchip.com /downloads/en/devicedoc/39632c.pdf

Pessoles X., Tournier C. (2009). Automatic polishing process of plastic injection molds on a 5-axis milling center. Journal of Materials Processing Technology, Volume 209, Issue 7. Pages 3665-3673, ISSN 0924-0136.

https://doi.org/10.1016/j.jmatprotec.2008.08.03 4.

Torrecilla E. (2019). El gran libro de CATIA. Editorial Marcombo. ISBN 9786075383880.

Zhao Y., Chang L. (2002). A micro-contact and wear model for chemical-mechanical polishing of silicon wafers. Wear, Volume 252, Issues 34. Pages 220-226, ISSN 0043-1648. https://doi.org/10.1016/S0043-1648(01)008717. 